\title{
СЕРІЯ «Державне управління економікою»
}

УДК $351: 336$

https://doi.org/10.52058/2708-7530-2021-3(9)-332-342

Свірко Світлана Володимирівна, доктор економічних наук, здобувач кафедри економічної безпеки, публічного управління та адміністрування, Державний університет «Житомирська політехніка», 10000, м. Житомир, вул. Чуднівська, 103, тел.: (0412) 24-14-22, e-mail: svs3@ukr.net, https//orcid.org/00000001-9157-4672

\section{МЕТОДОЛОГІЧНІ ПОЛОЖЕННЯ ДЕРЖАВНОГО УПРАВЛІННЯ БЮДЖЕТНОЮ БЕЗПЕКОЮ}

Анотація. В статті досліджено методологічні положення державного управління бюджетною безпекою, розбудова яких перебуває на стадії формування. Задля прискорення реалізації вказаного завдання автором опрацьовано загальні методологічні положення державного управління в цілому в розрізі принципів державного управління і методів державного управління та зроблено висновок про їх переважну екстраполяцію у площину державного управління бюджетною безпекою. У наслідок проведеного дослідження запропоновано здійснити: розподіл принципів державного управління бюджетною безпекою на принципи його методики та організації; розширення змісту принципів методики специфічними принципами, (безперервності (умотивовує послідовне постійне здійснення державного управління бюджетною безпекою з метою отримання ефективних результатів); незалежності (передбачає незалежність від інших органів державної влади); міжгалузевої компетентності (вимагає наявності знань не тільки в сфері державної безпеки, а й в економіці, зокрема в бюджетній сфері тощо)); розподіл принципів організації державного управління бюджетною безпекою на загальні принципи (цілісності елементів та зв'язків; динамічності та передбачуваності; безперервності) та специфічні принципи (організації процесу державного управління бюджетною безпекою (повноти, чіткого відображення, ритмічності, своєчасності, прямоточності, підпорядкованості, економічної доцільності, контролю) та організації праці виконавців функцій 3 державного управління бюджетною безпекою (зацікавленості, стимулювання, конкретності, комплексності, конструктивності, 
систематичності, пропорційності, гармонійності, підпорядкованості, економічної доцільності, контролю)); розширити науково-аналітичних методи державного управління бюджетною безпекою на користь методів стратегічного планування та контролю. Реалізація представлених новацій уможливить формування результативної та ефективної методико-організаційних положень державного управління бюджетною безпекою, що, в свою чергу, дозволить розробити грунтовні функціональні, організаційні, інформаційно-комунікаційні механізми державного управління бюджетною безпекою.

Ключові слова: методологія державного управління бюджетною безпекою, принципи методики державного управління бюджетною безпекою, принципи організації державного управління бюджетною безпекою.

Svirko Svitlana Volodymyrivna, Doctor of Economics, candidate of the Department of Economic Security, Public Administration and Administration, State University "Zhytomyr Polytechnic", 10000, Zhytomyr, st. Chudnivska, 103, tel .: (0412) 24-14-22, e-mail: svs3@ukr.net, https // orcid.org / 0000-0001-9157-4672

\section{METHODOLOGICAL PROVISIONS OF THE STATE BUDGET SECURITY MANAGEMENT}

Abstract. The article examines the methodological provisions of public administration of budget security, the development of which is at the stage of formation. In order to accelerate the implementation of this task, the author elaborated the general methodological provisions of public administration in general in terms of principles of public administration and methods of public administration and concluded that their predominant extrapolation to the plane of public administration budget security.As a result of the study, it is proposed to carry out: the division of the principles of public administration of budget security on the principles of its methodology and organization; expanding the content of the principles of methodology by specific principles (continuity (motivates the consistent ongoing implementation of public administration of budget security in order to obtain effective results); independence (implies independence from other public authorities); intersectoral competence (requires knowledge not only in state security but and in the economy, in particular in the budget sphere, etc.)); division of the principles of public budget security management into general principles (integrity of elements and connections; dynamism and predictability; continuity) and specific principles (organization of the public budget security management process (completeness, clear reflection, rhythm, timeliness, accuracy, subordination, economic feasibility), control) and organization of work of executors of functions on state management of budgetary security (interest, stimulation, 
concreteness, complexity, constructiveness, systematicity, proportionality, harmony, subordination, economic expediency, control)); expand scientific and analytical methods of public administration of budget security in favor of methods of strategic planning and control.Implementation of the presented innovations will enable the formation of effective and efficient methodological and organizational provisions of public administration of budget security, which, in turn, will develop thorough functional, organizational, information and communication mechanisms of public administration of budget security.

Keywords: methodology of public administration budget security, principles of methods of state management of budget security, principles of organization of state management of budget security.

Постановка проблеми. Будь-яка наука в своїх дослідах і пошуках має опиратись на певний інструментарій пізнання предмету та об'єктів. Сукупність таких методів формує методологія, яка у кожної науки є специфічною [1, с.451]. Наука про державне управління бюджетною безпекою знаходить на етапі свого становлення, при цьому формування чіткого методологічного підгрунтя ще не відбулося. Його відсутність унеможливлює розбудову загальної системи та механізму керівної дії щодо бюджетної безпеки, що негативно впливає не тільки на бюджетну систему і бюджетний процес в Україні, систему державних фінансів останньої, а й в цілому на соціально-економічний розвиток нашої країни. За цих умов дослідження методологічних положень бюджетної безпеки набуває особливої значущості та актуальності.

Аналіз останніх досліджень та публікацій. Розбудові теоретичних та практичних положень державного управління у різні часи присвятили свої праці такі вчені: В. Авер'янов, Г. Атаманчук, В. Князєв, В. Бакуменко, В. Луговий, Ю. Сурмін, О. Оболенський, Н. Нижник, Н. Виноградова та інші. Проблемні питання економічної безпеки опановували вчені: В.Горбулін, О. Власюк, А. Качинський, Г. Ситник, А. Семенченко, Я. Жаліло, А. Сухоруков, О. Шнипко, В. Мунтіян, В. Шлемко, В. Кириленко, 3. Варналій, Г. Пастернак-Таранушенко, В. Сенчагов, М. Коваленко, О. Користін, В. Нижник, Н. Абелгузин, В. Богомолов, Я. Чернятевич, А. Кулінська. Дослідження підсистеми державного управління економічною безпекою було представлено в працях: З. Гбур, С. Завгородньої, Т. Іванової, Н. Ткачової, П. Дмитрука, В. Котковського, А. Плакіди. Напрям науки про державне управління бюджетною безпекою опановували: А. Кулінської, Т. Луцик-Дубової, Н. Залізко, Т. Яковенко.

Попри здобутки щодо розбудови методології у сфері державного управління економічною безпекою, у тому числі частково і в сфері державного управління фінансовою безпекою, питання методологічних основ державного управління 
бюджетною безпекою залишилась вкрай не розвинутими. Вищевказане пояснює необхідність здійснення комплексного наукового дослідження методології державного управління бюджетною безпекою, яке пропонується розпочати 3 принципів та методів.

Виклад основного матеріалу. Провідне енциклопедичне видання 3 державного управління надають таке тлумачення поняттю “методологія державного управління” - “система способів здійснення та організації пізнавальної та практичної діяльності у сфері державного управління, що включає підсистему способів досліджень (понять, принципів, підходів, методів, методик, норм, парадигм тощо) у сфері державного управління та підсистему способів (принципів, принципів, підходів, методів, методик, процедур, технологій тощо) державно-управлінської діяльності [2, с.346]. Автори статті зазначають, що подальша деталізація об'єктного поля методології державного управління має бути ідентифікована в таких межах [2, с.347]: “створення та розвиток категорійного апарату державного управління, що передбачає обгрунтування, систематизацію, класифікацію та опис категорій, аналіз їх генезису, ролі в науці та практиці; формулювання принципів державного управління, аналіз їх наукової, оцінної та практичної транскрипцій; визначення норм пізнавальної, оцінної та практичної діяльності в державному управлінні; дослідження системи цінностей, їх зміни та ролей в державному управлінні, в пізнавальній, практичній і оцінній діяльності; вивчення парадигмальності державного управління, процесів розвитку та змін парадигм; аналіз теоретичного напрацювання державного управління, тенденцій його розвитку та методологічних функцій; обгрунтування методів державного управління, їх специфіки; забезпечення цілісності пізнавальної та практичної методологій, їх відкритості для методологічних інновацій."

Принцип за своєю природою являє собою “цетральне пояснення, особливість, покладена в основу створення або здійснення чого-небудь” [1, с.3615]. Принципи управління загалом вперше були систематизовані видатним практиком та науковцем в галузі управлінні Анрі Файолем і презентовані в книзі “Загальне та промислове управління” (1916). До їх складу вказний вчений включав [3]:

- «поділ праці- передоручення працівникам окремих операцій i, як наслідок, підвищення продуктивності праці, 3 огляду на те, що персонал отримує можливість зосередження своєї уваги;

- влада і відповідальність - право віддавати накази повинно бути врівноважено відповідальністю за їх наслідки; 
- дисципліна — необхідність дотримання правил, встановлених всередині організації; для підтримки дисципліни необхідна наявність на всіх рівнях керівників, здатних застосовувати адекватні санкції до порушників порядку;

- єдиноначальність - кожен працівник звітує тільки перед одним керівником і тільки від нього отримує розпорядження;

- єдність дій - група працівників повинна працювати тільки за єдиним планом, спрямованому на досягнення однієї мети;

- підпорядкованість інтересів - інтереси працівника або групи працівників не повинні ставитися вище за інтереси організації;

- винагорода - наявність справедливих методів стимулювання працівників;

- централізація - природний порядок в організації, що має керуючий центр; ступінь централізації залежить від кожного конкретного випадку;

- ієрархія - організаційна ієрархія, яка не повинна порушуватися, але яку, в міру можливості, необхідно скоротити, щоб уникнути шкоди;

- порядок - певне місце для кожної особи і кожна особа на своєму місці;

- справедливість - повага і справедливість адміністрації до підлеглих, поєднання доброзичливості та правосуддя;

- стабільність персоналу - плинність кадрів послаблює організацію і $є$ наслідком поганого менеджменту;

- ініціатива - надання можливості прояву особистої ініціативи працівникам;

- корпоративний дух - згуртованість працівників, єдність сили».

Грунтовність та значущість наведених принципів підтвердили роки, за які основна сукупність принципів управління фактично не змінилась, що підтверджує їх життєздатність та дієвість.

Повертаючись до об’єкта нашого дослідження, зауважимо, що наведене вище визначення “методології державного управління" дає підстави для пропозиції щодо розподілу принципів державного управління бюджетною безпекою на приниципи його методики та організації. Задля їх формування, звернімося до категорії вищого порядку - державного управління в цілому.

Принцип державного управління загалом являє собою “прояви закономірностей у державному управлінні, що відображені у вигляді певних положень, які застосовуються в теоретичній та практичний діяльності людей у сфері державного управління; це фундаментальні, науково-обгрунтовані, а в певних випадках- і законодавчо закріплені положення, відповідно до яких будується і функціонує система державого управління" [1, с.490 - 491]. До загальних принципів державого управління різні вчені на сьогодні відносять 
принципи [1, с.490 - 491; 2; 3; 4]: самоорганізації, зворотнього зв'язку, ресурсозбереження, оптимальності управління, релевантності, соціальної відповідальності, цілепокладання, доцільної структури управління, ідеальної бюрократичної організації управління, стратегічного мислення, прийняття рішень, об'єктивності державного управління, виперджуваного стану управління, демократизму, поділу влади, законності, оптимізації управління, єдності економіки та політики. Щодо принципів організації державного управління, зазначимо, що думка вчених розподілилась [1, с. 491, 501 - 502; 2 - 6]: перші відносять загальні принципи і до організаційних, другі - виокремлюють останні i включають до них принципи: пропорційності, неперервність, прямоточності, ритмічність, концентрація однорідних предметів праці, гнучкість.

Вочевидь, задля відображення всіх особливостей з керівної діяльності в сфері бюджетної безпеки, варто звернутись до особливостей останньої. Нагадаймо, що під бюджетною безпекою автор пропонує розуміти стан фінансової захищеності сектору загального державного управління, що характеризується платоспроможністю та фінансовою стійкістю держави, як економічного суб'єкту, що надає можливість інституціональним одиницям вказаного сектору реалізовувати повноваження на виконання функцій держави максимально результативно та ефективно в умовах мінливого середовища, зовнішніх та внутрішніх загроз. Роль і місце бюджетної безпеки в сучасному світі визначається такими позиціями останньої як:

- елемент забезпечення функціонування та існування інституту суверенної держави;

- складова багатоелементної системи державної безпеки;

- об’єкт державного управління;

- інструмент управління державними фінансами, у тому числі бюджетною системою та бюджетним процесом;

- засіб контролю за станом платоспроможності та фінансової стійкості держави в частині бюджетних ресурсів і коштів;

- фактор економічного розвитку країни та суб'єктів господарювання;

- детермінанта соціальної захищеності громадян країни;

- інформаційне джерел суспільства з приводу доречних даних про стан використання коштів його індивідів - учасників поповнення дохідної частини бюджетів;

- вид професійної діяльності;

- освітньо-наукове спрямування; 
Функціонально-цільовий апарат бюджетної безпеки виглядає наступним чином (таблиця 1).

\section{Таблиця 1}

\section{Функції та завдання бюджетної безпеки}

\begin{tabular}{|c|c|}
\hline Функція & Завдання \\
\hline інституційна & $\begin{array}{l}\text { забезпечення існування інституту держави та реалізації всіх її функцій (у } \\
\text { тому числі і щодо державної безпеки) та функціонування інституцій } \\
\text { сектору загального державного управління }\end{array}$ \\
\hline управлінська & $\begin{array}{l}\text { формування показників для прийняття рішень в сфері державного } \\
\text { управління: системою державних фінансів (у тому числі бюджетною } \\
\text { системою і процесом); державною безпекою (у тому числі економічною } \\
\text { (фінансовою (бюджетною безпекою) }\end{array}$ \\
\hline захисна & $\begin{array}{l}\text { захист прав громадян України, як учасників бюджетного процесу (перед } \\
\text { усім через систему оподаткування), в контексті ефективне використання } \\
\text { фінансових ресурсів країни, в поповненні яких вони приймають } \\
\text { безпосередню участь }\end{array}$ \\
\hline $\begin{array}{l}\text { контрольно- } \\
\text { індикативна }\end{array}$ & $\begin{array}{l}\text { вимірювання, оцінка та перевірка } \text { рівня } \text { платоспроможності } \\
\text { та } \\
\text { фінансової стійкості держави в межах системи державних фінансів }\end{array}$ \\
\hline економічна & $\begin{array}{l}\text { сприяння формуванню } \\
\begin{array}{l}\text { конкурентоздатності економіки країни та } \\
\text { суб’єктів }\end{array}\end{array}$ \\
\hline соціальна & сприяння забезпеченню громадян якісними державними послугами \\
\hline інформаційна & $\begin{array}{l}\text { забезпечення суспільства в межах реалізації принципу публічно щодо } \\
\text { державного управління відповідною достовірною та вірогідною } \\
\text { інформацією щодо бюджетної безпеки країни }\end{array}$ \\
\hline діяльнісна & $\begin{array}{l}\text { розвиток професіонального напряму в сфері бюджетної, фінансової, } \\
\text { економічної та державної безпеки }\end{array}$ \\
\hline $\begin{array}{c}\text { науково- } \\
\text { пізнавальна }\end{array}$ & розбудова науки про бюджетну безпеку \\
\hline
\end{tabular}

На підставі представленої інформації доречним буде розширення змісту принципів методики специфічними принципами, як то:

- безперервності (умотивовує послідовне постійне здійснення державного управління бюджетною безпекою з метою отримання ефективних результатів);

- незалежності (передбачає незалежність від інших органів державної влади);

- міжгалузевої компетентності (вимагає наявності знань не тільки в сфері державної безпеки, а й в економіці, зокрема в бюджетній сфері тощо);

Щодо принципів організації державного управління, як i в випадку 3 принципами методики державного управління бюджетною безпекою, пропонується первісно здійснити їх розподіл на 2 групи (виокремивши в другій групі підгрупи принципів процесу державного управління бюджетною безпекою 
та праці виконавців функцій $з$ державного управління бюджетною безпекою), а саме (рис.1) [8 - 10]:

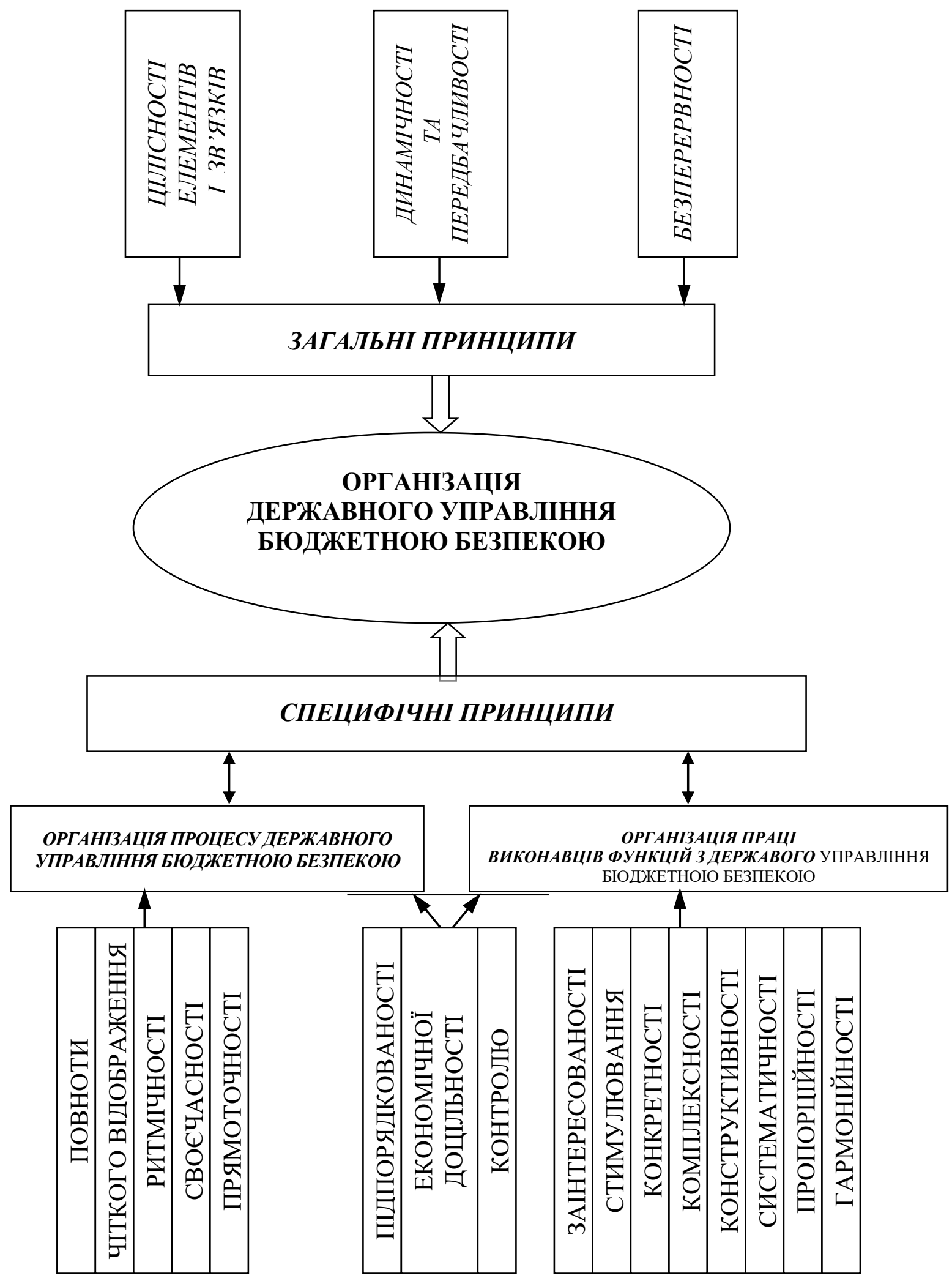

Рис. 1. Принципи організації державного управління бюджетною безпекою 
• загальні принципи;

- спеціальні принципи:

опринципи організації процесу державного управління бюджетною безпекою;

опринципи організації праці виконавців функцій 3 державного управління бюджетною безпекою;

Такий другорядний поділ на рівня специфічних принципів пояснюється подвійною характеристикою власне державного управління бюджетною безпекою, яке треба розглядати в контексті процесного та діяльнісного підходів, зокрема: як процесу в межах однойменної керуючої системи та виду професійної діяльності відповідних виконавців щодо державного управління бюджетною безпекою.

Питання ідентифікації методів державного управління бюджетною безпекою доречно розпочати з методів державного управління загалом. Так, під методами державного управління розуміють “систематизовані способи владного впливу державних органів на процеси суспільного і державного розвитку, діяльність державних структур і конкретних посадових осіб, що призводять до вирішення поставлених управлінських завдань на основі знання певних принципів державного управління" [1, с.313].

Традиційно, всі методи державного управління поділяють на дві групи; кожна з яких має свої підгрупи [1, с.313-314; 2 - 7]:

•загальні (застосовуються щодо державного управління загалом):

○ прямого адміністрування (правового регулювання, переконання, примушення тощо);

○ непрямого регулюючого впливу (виховання, стимулювання, демократизації управління, розміщення державних замовлень, маніпуляції тощо );

•спеціальні (застосовуються щодо окремих галузевих напрямів державного управління за функціями або сферами):

○ адміністративні (заборона, дозвіл, регламентація діяльності тощо);

○ економічні (матеріальне стимулювання, оподаткування, розподіл бюджетних ресурсів, кредитування, захист та заохочення конкуренції, створення невигідних умов одо монополії тощо)

○ соціально-політичні (інформування, реклама, залучення громадян до процесів державного управління, вирішення проблем соціальних груп, підвищення статусу відповідних 
категорій громадян, надання кращих можливостей до самореалізації тощо);

○ морально-етичні (заохочення, накладання стягнень);

○ науково-аналітичні (дослідження операцій, економічного аналізу, системного аналізу, аналізу політики);

Загальний аналіз представлених методів вказує на їх повну екстраполяцію на сферу державного управління бюджетною безпекою. Втім, потребує доопрацювання та уточнення блок науково-аналітичних методів, які не враховуються певних методів контролю та методів стратегічного планування зокрема.

Висновки. Розбудова методологічного інструментарію державного управління бюджетною безпекою перебуває на стадії формування. Задля прискорення реалізації вказаного завдання у наслідок проведеного дослідження запропоновано: розподіл принципів державного управління бюджетною безпекою на принципи його методики та організації; розширення змісту принципів методики специфічними принципами, (безперервності, незалежності, міжгалузевої компетентності); сформувати принципи організації державного управління за 2 групами (загальні (цілісності елементів та зв’язків; динамічності та передбачуваності; безперервності); специфічні (організації процесу державного управління бюджетною безпекою та організації праці виконавців функцій 3 державного управління бюджетною безпекою); розширення науково-аналітичних методів державного управління бюджетною безпекою на користь методів стратегічного планування та контролю. Реалізація представлених новацій уможливить формування результативної та ефективної методики та організації державного управління бюджетною безпекою.

\section{Jimepamypa:}

1. Куньч 3.Й. Універсальний словник української мови. - Тернопіль: Навчальна книга - Богдан, 2005. - 848c.

2. Енциклопедія державного управління: у 8 т. / Нац. акад. держ. упр. при Президентові України; наук.- ред. колегія: Ю.В. Ковбасюк (голова) та ін. - К.: НАДУ, 2011. Т. 2: Методологія державного управління / наук.- ред. колегія: Ю.П. Сурмін (співголова), П.І. Надолішній (співголова) та ін.-2011 -692 с.

3. Фойоль А. Общее и промышленное управление. URL: https:/gtmarket.ru/ library/basis/5783/5787

4. Державне управління : підручник : у 2 т. / Нац. акад. держ. упр. при Президентові України ; ред. кол. : Ю. В. Ковбасюк (голова), К. О. Ващенко (заст. голови), Ю. П. Сурмін (заст. голови) [та ін.]. - К. ; Дніпропетровськ : НАДУ, 2012. - Т. 1. - 564 с.

5. Ситник Г.П. Системний аналіз понятійно-категоріального апарату дослідження державного управління економічною безпекою / Г. П. Ситник, С. П. Завгородня // Державне управління: теорія та практика.- 2013. - № 2. - С. 82-89. 
6. Державне управління в децентралізація: Монографія/Відп. ред. Н.Р.Нижник; Кол. авт.: В.Б.Авер'янов, І.А.Грицяк, С.Д.Дубенко та ін. - К.: Вид-во УАДУ, 1997. - 448 с.

7. Державне управління: проблеми адміністративно-правової теорії та практики / [за заг. ред. В. Б. Авер'янова]. - К. : Факт, 2003. - 384 с.

8. Свірко С.В. Принципи організації бухгалтерського обліку// Вчені записки. Науковий збірник. - Вип.3. - К.: КНЕУ, 2001. - С.212-217.

9. Свірко С.В. Розвиток принципів організації бухгалтерського обліку: світовий історичний досвід та вітчизняні напрацювання сучасності // Вчені записки. Науковий збірник. Вип. 10. - К.: КНЕУ, 2008. - С. 202-207.

10. Свірко С.В. Бухгалтерський облік у бюджетних установах: методологія та організація: Монографія. - К.: КНЕУ, 2006. - 243с.

\section{References:}

1. Kun'ch, Z.J. (2005). Universal'nyj slovnyk ukrai'ns'koi' movy [Universal dictionary of the Ukrainian language]. Navchal'na knyga, Ternopil', Ukraine [in Ukrainian].

2. Kovbasjuk, Ju.V., Surmin, Ju.P. \& Nadolishnij, P.I. (2011). Encyklopedija derzhavnogo

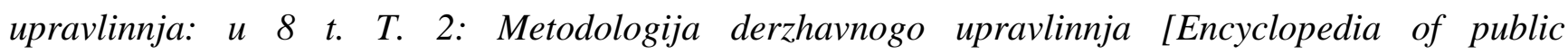
administration: in 8 vols. Vol. 2: Methodology of public administration]. Kyiv: NADU [in Ukrainian].

3. Fojol', A. (1916) "Obschee y promyshlennoe upravlenye" [General and industrial management]. URL: https://gtmarket.ru/library/basis/5783/5787 [in Russian].

4. Kovbasjuk, Ju.V., Vashhenko, K.O., Surmin, Ju.P. and other. (2012). Derzhavne upravlinnja u 2 t. [Public administration in 2 volumes.], Kyiv, Dnipropetrovs'k : NADU, T. 1. [in Ukrainian].

5. Sytnyk, G.P. and Zavgorodnja, S.P. (2013). "Systemnyj analiz ponjatijno-kategorial'nogo aparatu doslidzhennja derzhavnogo upravlinnja ekonomichnoju bezpekoju" [System analysis of the conceptual and categorical apparatus of research of state management of economic security ]. Derzhavne upravlinnja: teorija ta praktyka - Public administration: theory and practice, 2, 82-89. [in Ukrainian].

6. Aver'janov, V.B., Grycjak, I.A., Dubenko, S.D. and other. (1997). Derzhavne upravlinnja v Ukrai'ni: centralizacija $i$ decentralizacija [Public administration in Ukraine: centralization and decentralization]. Kyiv: Vyd-vo UADU [in Ukrainian].

7. Aver'janova, V.B. (2003). Derzhavne upravlinnja: problemy administratyvno-pravovoi' teorii' ta praktyky [Public administration: problems of administrative-legal theory and practice]. Kyiv: Fakt [in Ukrainian].

8. Svirko, S.V. (2001). Pryntsypy orhanizatsii bukhhalters'koho oblikuv[Principles of organization of accounting]. Vcheni zapysky. Naukovyj zbirnyk, 3., 212-217 [in Ukrainian].

9. Svirko, S.V.(2008). Rozvytok pryntsypiv orhanizatsii bukhhalters'koho obliku: svitovyj istorychnyj dosvid ta vitchyzniani napratsiuvannia suchasnosti [Development of principles of organization of accounting: world historical experience and domestic developments of modernity]. Vcheni zapysky. Naukovyj zbirnyk, 10, 202-207 [in Ukrainian].

10. Svirko S.V.(2006). "Bukhhalters'kyj oblik u biudzhetnykh ustanovakh: metodolohiia ta orhanizatsiia" [Accounting in budgetary institutions: methodology and organization]. Kyiv: KNEU [in Ukrainian]. 